\title{
Mineralogie antimonového výskytu Mikulovický vrch u Kadaně (Česká republika)
}

\section{Mineralogy of the antimony occurrence Mikulovický vrch near Kadaň (Czech Republic)}

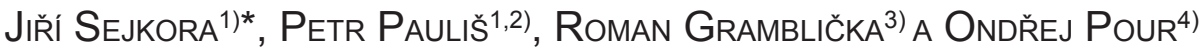 \\ 1)Mineralogicko-petrologické oddělení, Národní muzeum, Cirkusová 1740, 19300 Praha 9 - Horní Počernice; \\ *e-mail: jiri.sejkora@nm.cz \\ 2) Smíškova 564, 28401 Kutná Hora \\ 3) Severočeské doly a.s., ul. 5. května 213, 41829 Bílina \\ 4)Česká geologická služba, Geologická 6, 15200 Praha 5
}

Sejkora J, Pauliš P, GrambličKa R, Pour O (2020) Mineralogie antimonového výskytu Mikulovický vrch u Kadaně (Česká republika). Bull Mineral Petrolog 28(1): 48-57 ISSN 2570-7337

\begin{abstract}
Two rare sulfosalt minerals, fülöppite and plagionite, have been determined in samples from a small abandoned $\mathrm{Sb}$ occurrence Mikulovický vrch near Kadaň, northern Bohemia, Czech Republic. The more abundant fülöppite forms grey aggregates (up to $5 \mathrm{~mm}$ in size) with metallic lustre in quartz gangue and rare crystals up to $1.5 \mathrm{~mm}$ across in association with stibnite, plagionite, sphalerite, pyrite and arsenopyrite. Fülöppite is monoclinic, space group $C 2 / c$ with refined unit-cell parameters: a 13.443(2), b 11.737(2), c 16.953(2) $\AA, \beta$ 94.69(1) ${ }^{\circ}$ and $V$ 2665.9(5) $\AA^{3}$. Its empirical formula (mean of 93 point analyses) is $\left(\mathrm{Pb}_{2.80} \mathrm{Sn}_{0.01} \mathrm{Hg}_{0.01}\right)_{\Sigma 2.82} \mathrm{Sb}_{8.18} \mathrm{~S}_{14.99}$. Two types of plagionite were found as irregular aggregates up to $200 \mu \mathrm{m}$ in size in quartz gangue, ussualy in association with fülöppite. The first rarer one is close to the ideal composition with empirical formula (mean of 10 point analyses) $\left(\mathrm{Pb}_{4.90} \mathrm{Hg}_{0.01}\right)_{\Sigma 4.91} \mathrm{Sb}_{8.07} \mathrm{~S}_{17.02}$; the second is distinctly $\mathrm{Pb}$-poor with the calculated $N$ homologue number in the range of $1.37-1.74$ and empirical formula (mean of 62 point analyses) $\left(\mathrm{Pb}_{4.31} \mathrm{Sn}_{0.02} \mathrm{Hg}_{0.01}\right)_{\Sigma 4.34} \mathrm{Sb}_{8.53} \mathrm{~S}_{17.13}$. Determination of fülöppite and $\mathrm{Pb}$-poor plagionite were also confirmed by Raman spectroscopy. Gypsum, valentinite, native sulphur and jarosite was detected as products of weathering of primary mineralization.
\end{abstract}

Key words: fülöppite, plagionite, powder X-ray diffraction data, unit-cell parameters, chemical composition, Raman spectrocopy, Mikulovický vrch near Kadaň, Czech Republic

Obdrženo 29. 1. 2020; prijato 3. 4. 2020

\section{Úvod}

Fülöppit $\left(\mathrm{Pb}_{3} \mathrm{Sb}_{8} \mathrm{~S}_{15}\right)$ a plagionit $\left(\mathrm{Pb}_{5} \mathrm{Sb}_{8} \mathrm{~S}_{17}\right)$ ze skupiny plagionitu patři na českých lokalitách $\mathrm{k}$ poměrně vzácným sulfidům. Fülöppit byl zjištěn v podloží karbonu na dole Slaný (Žáček, Opluštil 1992; Žáček et al. 1994) jako olověně šedá, kovově lesklá, až $5 \mathrm{~mm}$ velká zrna a vzácněji i krystaly o velikosti do $0.4 \mathrm{~mm}$, vyskytující se $\checkmark$ asociaci se semseyitem. Vzácně se vyskytla jeho až $3 \mathrm{~cm}$ velká zrna na dole Lill v Príbrami (Sejkora, Litochleb 2003) a nověji byl zjištěn na ložisku Sb rud v Boněnově u Chodové Plané (Sejkora et al. 2017). Plagionit je uváděn $z$ několika míst $v$ přibramské rudní oblasti, $v$ makroskopické velikosti byl identifikován na historickém vzorku s antimonitem a zinkenitem z antimonitové žíly z 30. patra mezi doly Rudolf a Řimbaba v Bohutíně (Škácha 2015). V Bohutíně byl nalezen i na Príčné žíle (Bambas 1990) a Litochleb et al. (1994) ho zjistili i v tzv. plstnatých rudách $z$ haldy dolu Lill. Nedávno byl popsán i jako součást submikroskopických srůstů s fülöppitem na Sb ložisku v Boněnově (Sejkora et al. 2017).

Recentní nález fülöppitu a plagionitu na drobném antimonitovém výskytu na Mikulovickém vrchu u Kadaně je, stejně jako popis celé zjištěné minerální asociace, námětem tohoto príspěvku.

\section{Historie a geologie lokality}

Studovaný výskyt Sb rud vystupuje na západním úpatí dvojvrcholu Mikulovický vrch - Špičák, mezi Kadaní a Kláštercem nad Ohří (2.5km z. od Kadaně, severní Čechy). Zrudnělá křemenná žíla probíhající migmatitizovanou pararulou byla otevřena krátkou, dnes již zcela zasucenou průzkumnou štolou (obr. 1) neznámého stáří, jejíž ústí se nachází na břehu Hradišt'ského potoka, asi $100 \mathrm{~m}$ od jeho vtoku do Ohře a asi $250 \mathrm{~m}$ západně od kóty 407 $\mathrm{m}$ n. m. GPS souřadnice lokality jsou: $50^{\circ} 22^{\prime} 49^{\prime \prime} \mathrm{N}, 13^{\circ}$ 14' 5" $\mathrm{E}$.

Jediné historické zmínky o dolování v prostoru vrchu Špičák (něm. Spitzberg) pocházejí z počátku 19. století. $\checkmark$ roce 1801 zmiňuje Reuss (in Kratochvíl 1963) těžbu kobaltové rudy (smaltin - grauer Speiskobalt) provázené pyritem a rohovcovou žilovinou $v$ rule. Štola, která byla zaražena na severní straně vrchu, sledovala žílu o mocnosti $30 \mathrm{~cm}$. Tato historická zmínka o starém dolování nemá však patrně s popisovanou lokalitou žádnou spojitost. Jedinou relevantní informaci o této lokalitě podává Rezek (1982), který v rámci revize starých důlních děl na Chomutovsku objevil zbytky odvalu zabořené štoly na západním svahu Špičáku. Štola, která byla ražena v migmatitech oháreckého krystalinika, sledovala křemennou žílu 
pravděpodobně směru JV - SZ, jak nasvědčuje orientace propadlin $v$ terénu nad zabořeným ústím. $V$ křemenné žilovině zjistil Rezek (1982) shluky jehliček antimonitu nepatrných rozměrů (pod $0.0 \mathrm{X} \mathrm{mm}$ ) a v dutinách ojedinělé jehličkovité agregáty antimonitu, jejichž velikost nepřesahuje 2 $\mathrm{mm}$. Místy jsou vtroušená zrna pyritu a markazitu o velikosti desetin $\mathrm{mm}$. Autorem této krátké nálezové zprávy bylo též provedeno kvantitativní stanovení obsahu zlata $v$ žilovině metodou atomové absorpce, který činil $0.12 \mathrm{~g} / \mathrm{t}$. O stáří těchto důlních prací neexistují žádné dostupné informace; důlní dílo není evidováno v registru starých důlních děl spravovaném Ministerstvem životního prostředí, jak vyplývá z mapových aplikací „stará dưlní díla a poddolovaná území" na webových stánkách České geologické služby - Geofondu.

Na základě výše uvedené zprávy Rezka (1982) byl tento výskyt znovuobjeven třetím z autorů (RG) v únoru 2017. Charakter lokality se od osmdesátých let minulého stolet nezměnil. Lokalitu tvoří zcela zavale-

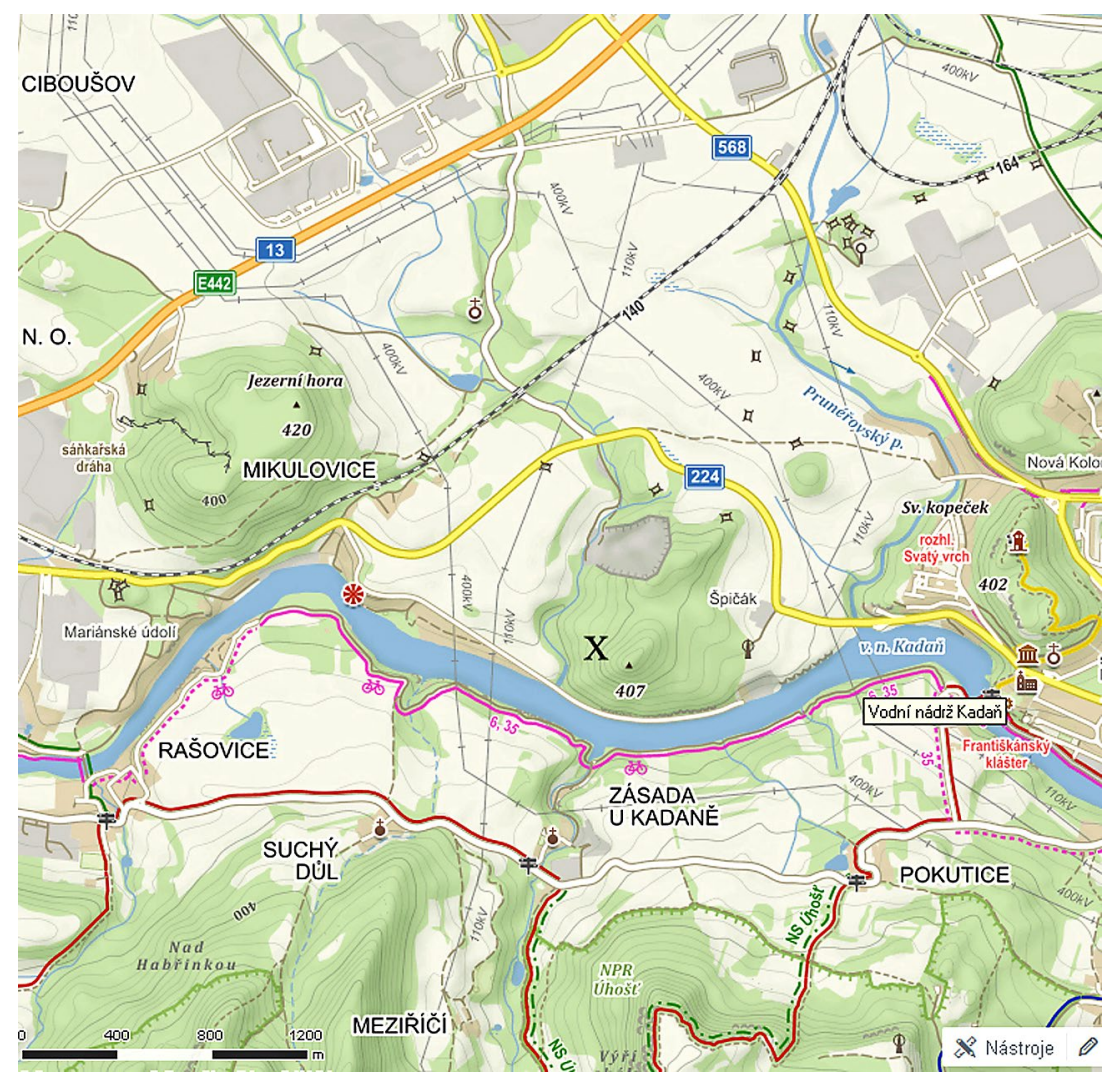

Obr. 1 Plánek lokality Mikulovický vrch u Kadaně (upraveno podle www.mapy.cz).

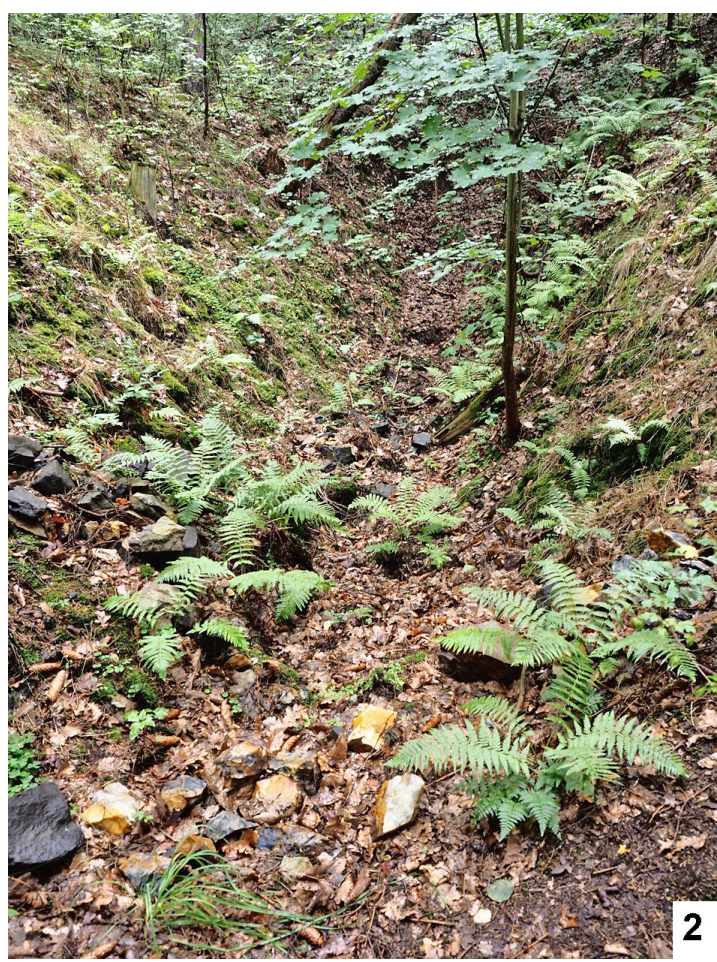

Obr. 2 Zabořené ústí štoly na úpatí Mikulovického vrchu, foto P. Pauliš (2018).

Obr. 3 Drobný odval s rudninou u štoly, foto P. Pauliš (2018).
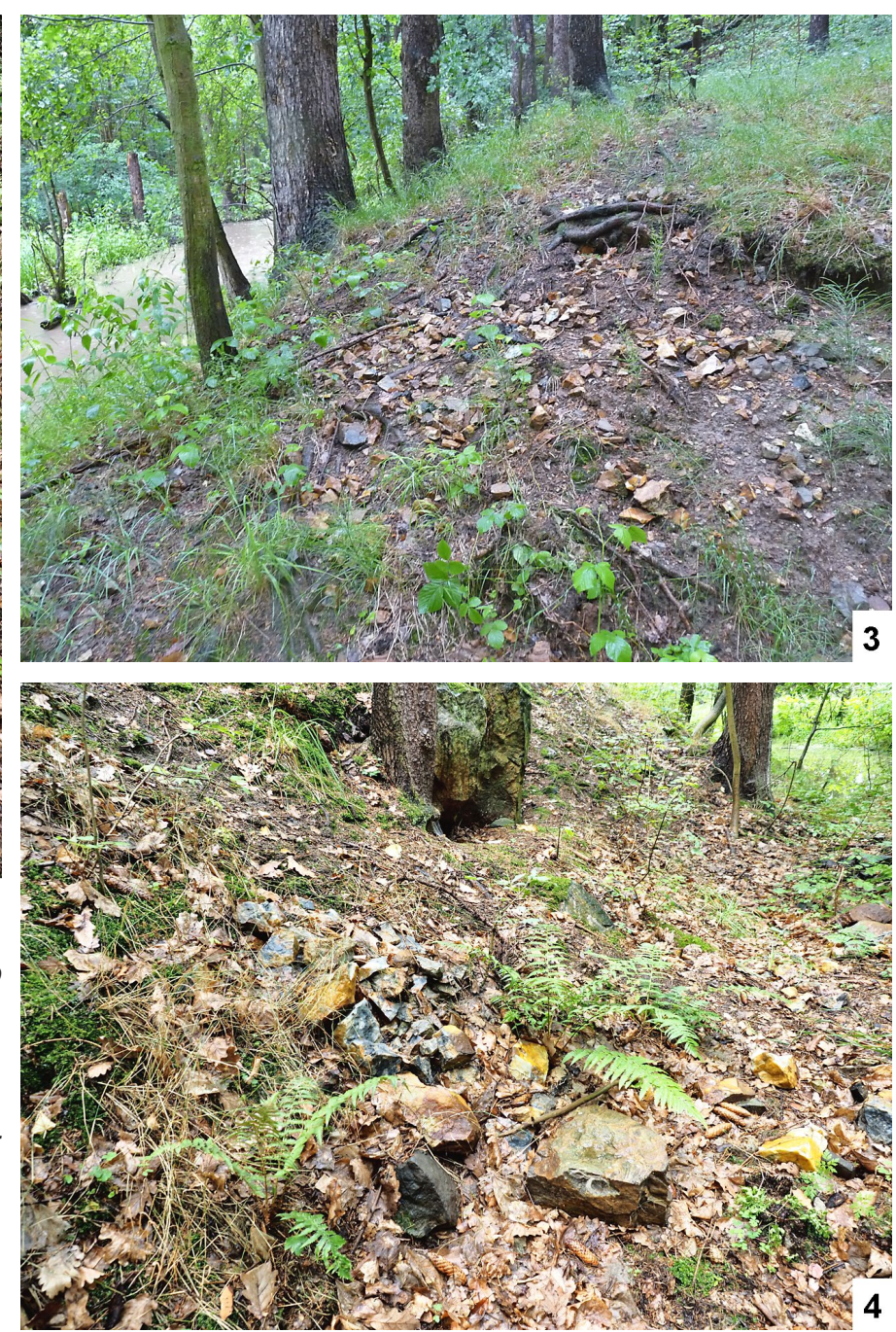

Obr. 4 Rudnina u štoly, foto P. Pauliš (2018). 
ná štola s dobře patrným zářezem (obr. 2) a malou, nenápadnou haldičkou po pravé straně ve směru od štoly (obr. 3, 4). Nad ní se ve svahu nachází propad či zavalená šachtice $v$ podobě asi $2 \mathrm{~m}$ hluboké pinky. Štola zde sledovala křemennou žílu o předpokládané mocnosti 30 - $50 \mathrm{~cm}$, prorážející světlou, drobnozrnnou dvojslídnou migmatitizovanou pararulu, tvořící podklad terciérním vulkanitům - bazaltoidům a vulkanickým tufům, které tvoří vlastní masiv vrchu.

\section{Metodika výzkumu}

Rentgenová prášková difrakční data byla získána pomocí práškového difraktometru Bruker D8 Advance (Národní muzeum, Praha) s polovodičovým pozičně citlivým detektorem LynxEye za užití CuKa záření (40 kV, $40 \mathrm{~mA}$ ). Práškové preparáty byly naneseny $v$ acetonové suspenzi na nosič zhotovený z monokrystalu křemíku a následně pak byla pořízena difrakční data ve step-scanning režimu (krok $0.01^{\circ}$, načítací čas $8 \mathrm{~s} /$ krok detektoru, celkový čas experimentu cca 15 hod.). Pozice a intenzity jednotlivých difrakčních maxim byly zpřesněny pomocí programu ZDS (Ondruš 1993) za užití profilové funkce
Pearson VII. Mřižkové parametry byly zpřesněny metodou nejmenších čtverců pomocí programu Burnhama (1962), iniciální hodnoty byly použity z práce Nuffield (1975).

Předběžná identifikace zdejší rudní mineralizace i dalších minerálů (ryzí síra, valentinit) byla provedena energiově disperzním spektrometrem Oxford Instruments XMAX 80 spojeným se skenovacím elektronovým mikroskopem Tescan Mira3 (Česká geologická služba, Praha), operujícím při urychlovacím napětí $15 \mathrm{kV}$ na naleštěných nábrusech a zrnech minerálů.

Chemické složení mineralizace bylo kvantitativně studováno pomocí elektronového mikroanalyzátoru Cameca SX100 (Národní muzeum, Praha, analytik Jiří Sejkora, Zdeněk Dolníček) za podmínek: vlnově disperzní analýza, napětí $25 \mathrm{kV}$, proud $20 \mathrm{nA}$, průměr svazku $0.7 \mu \mathrm{m}$, standardy a použité analytické čáry: $\mathrm{Ag}(\mathrm{AgL} \alpha)$, apatit (CaKa, PKa), $\mathrm{Au}(\mathrm{AuM \alpha})$, baryt (BaLa), $\mathrm{Bi}_{2} \mathrm{Se}_{3}$ $(\mathrm{BiM} \beta), \mathrm{CdTe}(\mathrm{CdL} \alpha)$, Co (CoKa), CuFeS $(\mathrm{CuKa}, \mathrm{SK} \alpha)$, $\mathrm{FeS}_{2}$ (FeKa), GaAs (GaLa), Ge (GeLa), HgTe (HgLa), InAs (InL $\alpha), \mathrm{Mn}(\mathrm{MnK} \alpha), \mathrm{NaCl}(\mathrm{ClK \alpha})$, NiAs (AsL $\beta), \mathrm{Ni}$ (NiKa), PbS (PbMa), PbSe (SeL $\beta)$, PbTe (TeL $\alpha)$, sanidin

Tabulka 1 Chemické složení sulfosolí použitých jako referenční standardy pro Ramanovu spektroskopii

fülöppit, Baia Mare, Rumunsko (NM P1N 55988), potvrzen PXRD

Ag 0 - 0.35, Pb 27.54 - 30.27, Sn 0.10 - 0.18, Sb 45.81 - 49.68, S 22.11 - 23.28 hm. \%

$\mathrm{Pb}_{2.86} \mathrm{Ag}_{0.04} \mathrm{Sn}_{0.02} \mathrm{Sb}_{8.16} \mathrm{~S}_{14.91}$ (průměr 13 bodových analýz, báze $26 \mathrm{apfu}$ ), $\mathrm{N}=0.85-1.08$

plagionit, Wolfsberg, SRN (NM P1N 547), potvrzen PXRD

Pb 39.79 - 40.24, Sn 0.07 - 0.13, Sb 37.94 - 38.40, S 21.15 - 21.43 hm. \%

$\mathrm{Pb}_{4.93} \mathrm{Sn}_{0.02} \mathrm{Sb}_{8.01} \mathrm{~S}_{17.03}$ (průměr 10 bodových analýz, báze 30 apfu), $\mathrm{N}=1.95-1.99$

scainiit, Dúbrava, Slovensko, potvrzen PXRD

Pb 35.72 - 37.03, Sb 41.12 - 42.08, Bi 0 - 0.53, S 19.40 - 20.59, Cl 0.07 - 0.14 hm. \%

$\mathrm{Pb}_{15.08}\left(\mathrm{Sb}_{29.33} \mathrm{Bi}_{0.06}\right)_{\Sigma 29.39} \mathrm{~S}_{53.52} \mathrm{O}_{5.52} \mathrm{Cl}_{0.25}$ (průměr 14 bodových analýz, báze $98 \mathrm{apfu}$ )

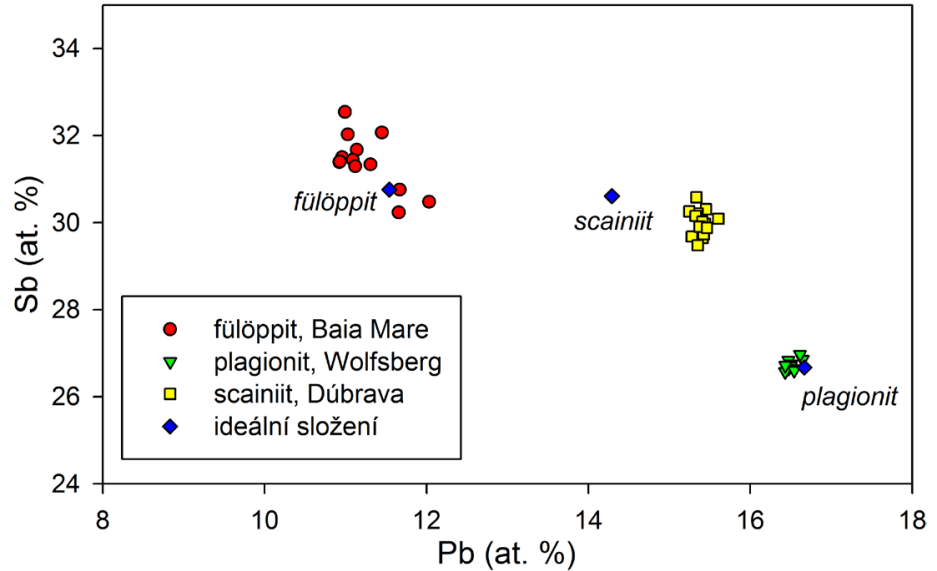

Obr. 5 Graf Pb vs. Sb (at. \%) pro sulfosole použité jako referenční standardy pro Ramanovu spektroskopii.
Obr. 6 Ramanova spektra sulfosolí použitých jako referenční standardy (tab. 1).

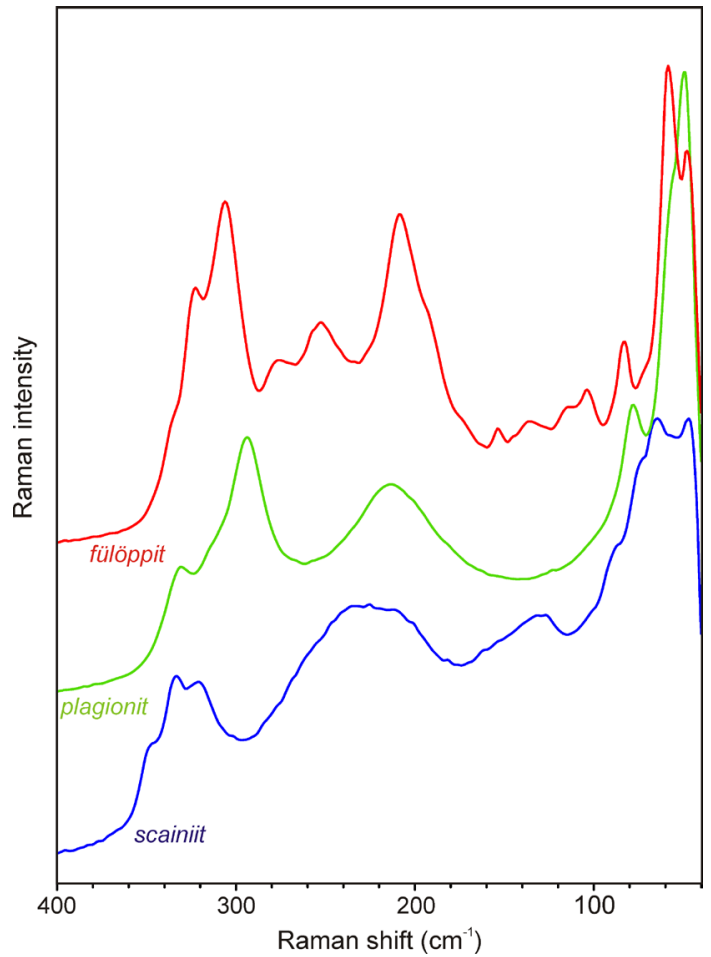


(KKa), $\mathrm{Sb}_{2} \mathrm{~S}_{3}(\mathrm{SbL} \alpha), \mathrm{Sn}(\mathrm{SnL} \alpha)$ a $\mathrm{ZnS}(\mathrm{ZnK \alpha})$. Obsahy výše uvedených prvků, které nejsou zahrnuty $v$ tabulkách, byly kvantitativně analyzovány, ale zjištěné obsahy byly pod detekčním limitem (cca 0.03 - 0.05 hm. \% pro jednotlivé prvky). Získaná data byla korigována za použití software PAP (Pouchou, Pichoir 1985). Homologové číslo $N$ minerálů skupiny plagionitu bylo vypočteno podle vztahu $N=4 \mathrm{~Pb} / \mathrm{Sb}-0.5$ (Makovicky 2019).

Ramanova spektra byla pořízena za pomoci disperzního spektrometru DXR (Thermo Scientific) spojeného $s$ konfokálním mikroskopem Olympus (Národní muzeum Praha). Podmínky měření: zvětšení objektivu 100×, použitý laser $633 \mathrm{~nm}$, rozsah měření $40-4000 \mathrm{~cm}^{-1}$, doba expozice $10 \mathrm{~s}$, celkový počet expozic 100, výkon laseru $1 \mathrm{~mW}$ (sulfidy) a $8 \mathrm{~mW}$ (valentinit), použitá apertura $25 \mu \mathrm{m}$ (sulfidy) a $50 \mu \mathrm{m}$ (valentinit) pinhole, velikost měřené stopy $0.5 \mu \mathrm{m}$. Reprezentativní spektra byla vybrána ze setu spekter měřených na různých zrnech/krystalech pro získání nejlepšího odstupu signálu od pozadí a minimálního rozsahu fluorescence. Možné termické poškození měřených bodů sledované pomocí vizuální kontroly povrchu vzorku po měření a prípadných změn spektra v průběhu měření, nebylo zjištěno. Spektrometr byl kalibrován pomocí softwarově řízené procedury s využitím emisních linií neonu (kalibrace vlnočtu), Ramanových pásů polystyrenu (kalibrace frekvence laseru) a standardizovaného zdroje bílého světla (kalibrace intenzity). Získaná spektra byla zpracována pomocí programu Omnic 9 (Thermo Scientific). Vzhledem k nedostatečné kvalitě Ramanových spekter studovaných sulfidů $v$ databázi RRUFF (Lafuente et al. 2015) byla pro identifikaci fází naměřena referenční spektra z jednoznačně definovaných přírodních fází (tab. 1, obr. 5, 6).

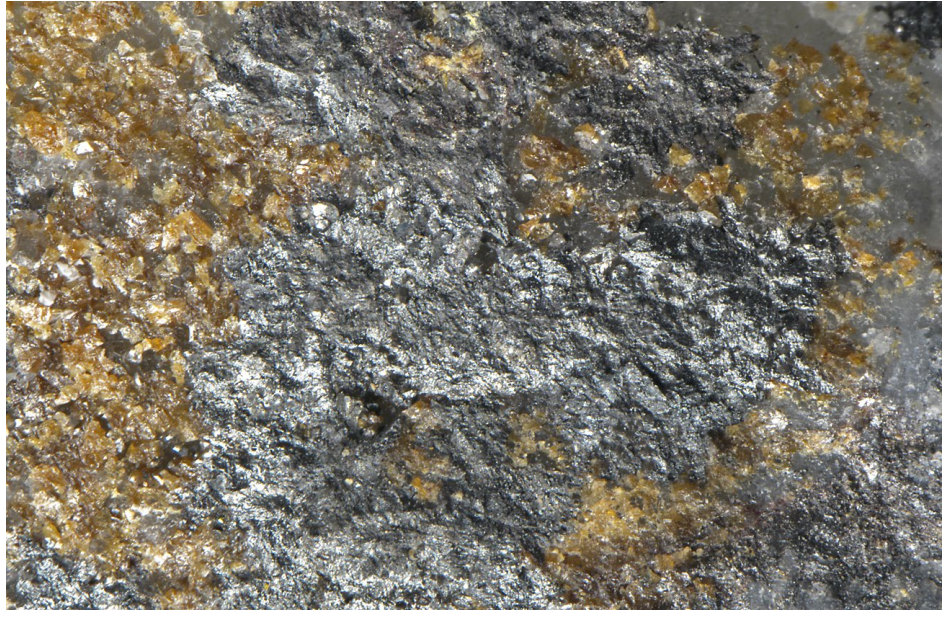

Obr. 7 Kovově šedé agregáty fülöppitu v křemenné žilovině; Mikulovický vrch; šírka záběru $8 \mathrm{~mm}$, foto J. Sejkora.

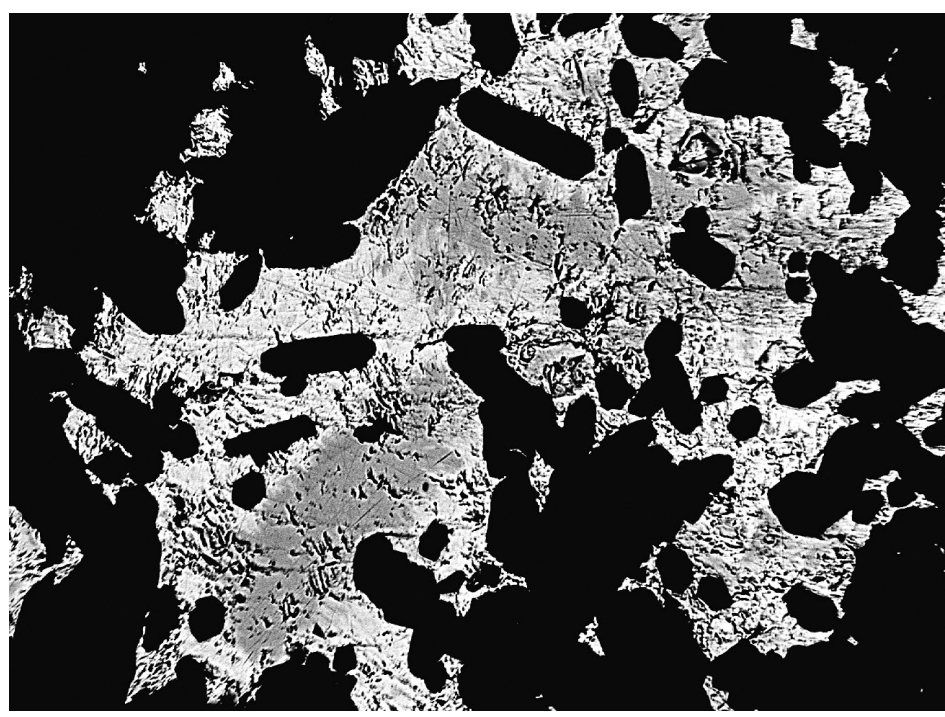

Obr. 8 Agregáty fülöppitu (tmavší) srůstající s plagionitem (světlejši) $v$ kremenné žilovině; Mikulovický vrch; šířka záběru $700 \mu \mathrm{m}$, foto v BSE J. Sejkora.

Tabulka 2 Rentgenová prášková data fülöppitu z Mikulovického vrchu

\begin{tabular}{|c|c|c|c|c|c|c|c|c|c|c|c|c|c|c|c|c|c|}
\hline$h$ & $k$ & 1 & $d_{o b s}$ & $I_{o b s}$ & $d_{\text {calc }}$ & $h$ & $k$ & 1 & $d_{o b s}$ & $I_{o b s}$ & $d_{\text {calc }}$ & $h$ & $k$ & 1 & $d_{o b s}$ & $I_{o b s}$ & $d_{\text {calc }}$ \\
\hline 0 & 0 & 2 & 8.458 & 3.0 & 8.448 & 2 & 2 & -4 & 3.138 & 55.6 & 3.137 & 4 & 4 & -3 & 2.0926 & 4.9 & 2.0936 \\
\hline 1 & 1 & -2 & 6.286 & 52.6 & 6.275 & 1 & 1 & 5 & 3.106 & 18.0 & 3.101 & 6 & 2 & 1 & 2.0522 & 10.9 & 2.0523 \\
\hline 0 & 2 & 1 & 5.551 & 6.8 & 5.544 & 2 & 2 & 4 & 2.974 & 10.9 & 2.973 & 1 & 1 & 8 & 2.0296 & 5.6 & 2.0295 \\
\hline 2 & 0 & 2 & 5.063 & 3.4 & 5.052 & 3 & 3 & -1 & 2.927 & 45.9 & 2.926 & 5 & 1 & -6 & 1.9965 & 8.6 & 1.9961 \\
\hline 1 & 1 & -3 & 4.873 & 12.4 & 4.868 & 4 & 2 & -1 & 2.905 & 14.3 & 2.901 & 6 & 2 & 2 & 1.9910 & 7.5 & 1.9910 \\
\hline 2 & 2 & 0 & 4.417 & 1.5 & 4.414 & 3 & 1 & 4 & 2.862 & 7.9 & 2.862 & 3 & 3 & 6 & 1.9814 & 14.3 & 1.9820 \\
\hline 2 & 2 & -1 & 4.332 & 3.0 & 4.328 & 4 & 2 & 1 & 2.833 & 19.2 & 2.833 & 3 & 1 & -8 & 1.9452 & 5.3 & 1.9453 \\
\hline 3 & 1 & 0 & 4.178 & 5.3 & 4.174 & 3 & 3 & -2 & 2.827 & 29.7 & 2.827 & 0 & 0 & 4 & 1.9102 & 5.3 & 1.9107 \\
\hline 0 & 2 & 3 & 4.067 & 8.3 & 4.064 & 2 & 2 & -5 & 2.756 & 58.3 & 2.756 & 4 & 4 & -5 & 1.8947 & 7.1 & 1.8952 \\
\hline 3 & 1 & 1 & 3.983 & 4.1 & 3.982 & 4 & 2 & 2 & 2.691 & 10.5 & 2.692 & 7 & 1 & 0 & 1.8889 & 2.6 & 1.8890 \\
\hline 1 & 1 & -4 & 3.895 & 100.0 & 3.893 & 3 & 3 & -3 & 2.668 & 16.2 & 2.668 & 2 & 6 & -1 & 1.8707 & 5.6 & 1.8710 \\
\hline 1 & 3 & 0 & 3.758 & 18.4 & 3.756 & 2 & 4 & -1 & 2.668 & 16.2 & 2.668 & 0 & 4 & 7 & 1.8630 & 6.0 & 1.8641 \\
\hline 1 & 3 & -1 & 3.686 & 22.6 & 3.684 & 2 & 2 & 5 & 2.614 & 4.1 & 2.616 & 5 & 1 & -7 & 1.8474 & 2.6 & 1.8477 \\
\hline 1 & 3 & 1 & 3.649 & 11.3 & 3.648 & 3 & 1 & 5 & 2.533 & 1.1 & 2.533 & 5 & 1 & 6 & 1.8423 & 9.0 & 1.8433 \\
\hline 3 & 1 & 2 & 3.635 & 22.6 & 3.634 & 2 & 0 & 6 & 2.523 & 13.9 & 2.523 & 3 & 5 & -5 & 1.7996 & 6.4 & 1.8008 \\
\hline 2 & 2 & -3 & 3.570 & 13.5 & 3.569 & 2 & 2 & -6 & 2.4340 & 16.2 & 2.4343 & 3 & 1 & -9 & 1.7634 & 3.0 & 1.7633 \\
\hline 2 & 2 & 3 & 3.389 & 20.7 & 3.387 & 1 & 1 & 7 & 2.2997 & 3.0 & 2.2970 & 2 & 2 & -9 & 1.7612 & 8.6 & 1.7621 \\
\hline 3 & 1 & 3 & 3.238 & 28.9 & 3.237 & 0 & 4 & 5 & 2.2155 & 5.6 & 2.2156 & 5 & 5 & 1 & 1.7465 & 6.0 & 1.7465 \\
\hline 1 & 1 & -5 & 3.215 & 26.3 & 3.214 & 5 & 3 & -1 & 2.2113 & 13.5 & 2.2114 & 6 & 2 & -6 & 1.7412 & 2.6 & 1.7416 \\
\hline 4 & 0 & -2 & 3.207 & 35.0 & 3.205 & 1 & 5 & 3 & 2.1291 & 43.2 & 2.1285 & & & & & & \\
\hline
\end{tabular}




\section{Charakteristika primární mineralizace}

Studované vzorky byly odebrány jak z haldového materiálu, tak zejména $z$ balvanů ležících $v$ zářezu před štolou (obr. 4). Zatímco materiál v haldě obsahuje převážně hluchou až slabě zrudněnou světlou křemennou žilovinu $s$ pyritem, $v$ zářezu bylo nalezeno několik až půl metru velkých balvanů tmavé, relativně bohatě zrudněné žiloviny s antimonitem a doprovodnou mineralizací. Žilovina má brekciovitou texturu a je tvořená křemenem, uzavírajícím četné úlomky světlé pararuly, místy silně altero- vané a limonitizované. Křemen je převážně masivní až rohovcovitý, místy s patrnou proudovou texturou, s řídkými drobnými dutinami puklinovitého tvaru s drobně drúzovitým povrchem. Až $3 \mathrm{~mm}$ dlouhé krystaly křemene jsou krátce až dlouze prizmatické. Barva křemene je bělavá až modravě šedá, s přibývajícím obsahem antimonitu až tmavě šedá.

Fülöppit vytváří kovově šedá neštěpná zrna a jejich shluky o velikosti do $5 \mathrm{~mm}$, které zarůstají do antimonitem bohatých partií křemenné žiloviny (obr. 7), místy srůstá s

Tabulka 3 Parametry základní cely fülöppitu (pro monoklinickou prostorovou grupu C2/c)

\begin{tabular}{ccccc}
\hline & tato práce & Sejkora et al. (2017) & Nuffield (1975) & Edenharter, Nowacki (1975) \\
\hline$a[\AA]$ & $13.443(1)$ & $13.444(4)$ & $13.441(15)$ & $13.435(5)$ \\
$b[\AA]$ & $11.737(2)$ & $11.727(2)$ & $11.726(15)$ & $11.727(4)$ \\
$c[\AA]$ & $16.953(2)$ & $16.934(3)$ & $16.930(15)$ & $16.934(5)$ \\
$\beta\left[^{\circ}\right]$ & $94.69(1)$ & $94.7(4)$ & $94.71(8)$ & $94.70(8)$ \\
$V\left[\AA^{3}\right]$ & $2665.9(5)$ & $2661(1)$ & 2659.31 & 2659.0 \\
\hline
\end{tabular}

Tabulka 4 Chemické složení fülöppitu z Mikulovického vrchu (hm. \%)

\begin{tabular}{|c|c|c|c|c|c|c|c|c|c|c|c|c|c|c|c|}
\hline & mean & 1 & 2 & 3 & 4 & 5 & 6 & 7 & 8 & 9 & 10 & 11 & 12 & 13 & 14 \\
\hline$b$ & 28.19 & 25.45 & 26.08 & 26.46 & 28.03 & 3.15 & 28.20 & 28.68 & 28.49 & 28.60 & 28.79 & 28.86 & 28.90 & 29.52 & 9.71 \\
\hline Sn & 0.06 & 0.09 & 0.07 & 0.09 & 0.08 & 0.00 & 0.00 & 0.11 & 0.09 & 0.10 & 0.15 & 0.08 & 0.11 & 0.10 & 0.11 \\
\hline $\operatorname{tg}$ & 0.11 & 0.00 & 0.00 & 0.00 & 0.63 & 0.17 & 0.11 & 0.00 & 0.47 & 0.08 & 0.27 & 0.00 & .06 & 0.21 & 0.37 \\
\hline W & 48.35 & 51.04 & 49.91 & 49.83 & 48.98 & 48.97 & 48.38 & 48.41 & 47.49 & 47.60 & 47.50 & 48.30 & 47.84 & 46.83 & 47.92 \\
\hline Se & 0.01 & 0.00 & 0.00 & 0.00 & 0.00 & 0.00 & 0.00 & 0.00 & 0.00 & 0.00 & 0.00 & 0.00 & 0.00 & 0.23 & 0.04 \\
\hline$S$ & 23.33 & 24.25 & 23.69 & 23.46 & 23.57 & 23.38 & 23.38 & 23.44 & 23.25 & 23.33 & 23.15 & 22.96 & 23.08 & 23.18 & 22.87 \\
\hline otal & 100.06 & 100.83 & 99.75 & 99.90 & 101.291 & 100.671 & 100.071 & 100.64 & 99.79 & 99.71 & 99.86 & 100.20 & 99.99 & 100.07 & 101.02 \\
\hline $\mathrm{Pb}$ & 2.803 & .458 & 2.566 & 2.614 & 2.7 & 2 & 01 & 38 & 2.847 & 2.853 & 2.882 & 91 & 2.893 & 2.952 & 2.974 \\
\hline in & 0 & 0.0 & 0 & 0.0 & 4 & 0 & 00 & 19 & 0. & 17 & 26 & 14 & 19 & 17 & 019 \\
\hline $\mathrm{tg}$ & 0.012 & 0.000 & 0.000 & 0.000 & 0.064 & 0.017 & 0.011 & 0.000 & 0.049 & 0.008 & 0.028 & 0.000 & 0.006 & 0.022 & 0.038 \\
\hline $\bar{\Sigma}$ & 2.825 & 2.474 & 2.578 & 2.630 & 2.833 & 2.803 & 2.813 & 2.857 & 2.911 & 2.879 & 2.936 & 2.905 & 2.919 & 2.991 & 3.032 \\
\hline Sb & 8.180 & 8.390 & 8.358 & 8.378 & 8.194 & 8.247 & 8.179 & 8.153 & 8.076 & 8.081 & 8.091 & 8.234 & 8.151 & 7.970 & 8.164 \\
\hline $\mathrm{Se}$ & 0.003 & 0.000 & 0.000 & 0.016 & 0.000 & 0.000 & 0.000 & 0.000 & 0.000 & 0.000 & 0.000 & 0.000 & 0.000 & 0.060 & 0.011 \\
\hline S & 14.992 & 15136 & 15064 & & 149731 & & 15008 & 14990 & 15012 & 15.040 & 1407 & $1406 r$ & 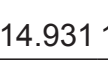 & 14.979 & 14.794 \\
\hline $\bar{\Sigma}$ & 14.99 & 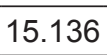 & 5064 & 400 & 1073 & 1050 & 00 & 14000 & .01 & .04 & .97 & 4.86 & 4.93 & 5.039 & 14.805 \\
\hline $\bar{N}$ & 0.88 & 0.68 & 0.73 & 0.76 & 0.88 & 0.86 & 0.88 & 0.90 & 0.94 & 0.92 & 0.95 & 0.91 & 0.93 & 1.00 & 0.99 \\
\hline
\end{tabular}

Mean - průměr 93 bodových analýz, 1 - 14 reprezentativní bodové analýzy; koeficienty empirických vzorců počíány na bázi 26 apfu; $N$ - číslo homologu plagionitové skupiny (Makovicky 2019).

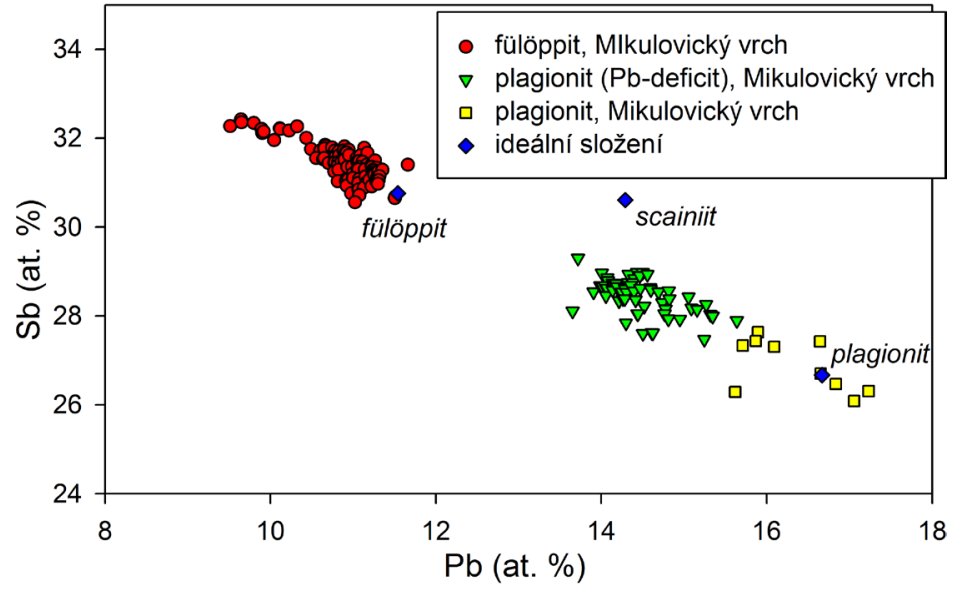

Obr. 9 Graf Pb vs. Sb (at. \%) pro sulfosole z Mikulovického vrchu u Kadaně. 


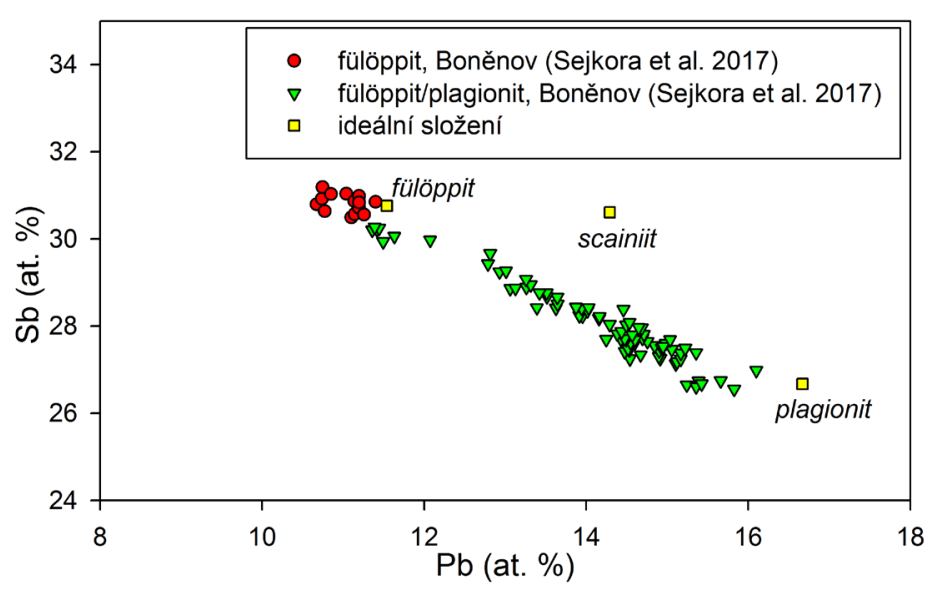

Obr. 10 Graf Pb vs. Sb (at. \%) pro fülöppit a (sub)mikroskopické srůsty fülöppitu a plagionitu z Boněnova (Sejkora et al. 2017).

Obr. 11 Ramanovo spektrum fülöppitu z Mikulovického vrchu v porovnání s referenčním spektrem fülöppitu z Baia Mare.

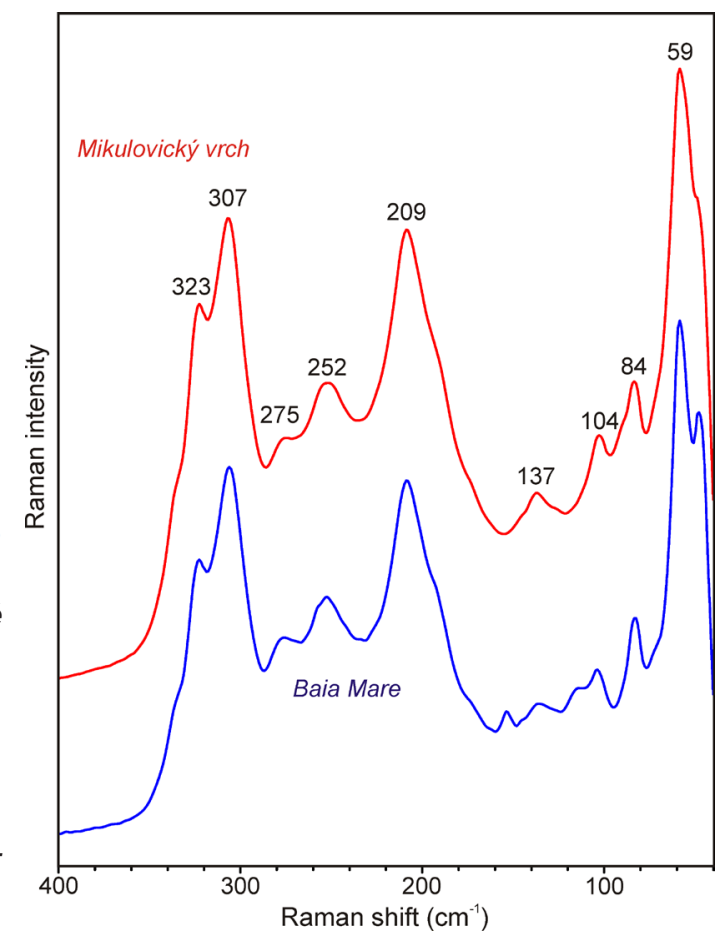

Tabulka 5 Chemické složení plagionitu z Mikulovického vrchu (hm. \%)

\begin{tabular}{lrrrrrrrrrrr}
\hline & mean & 1 & 2 & 3 & 4 & 5 & 6 & 7 & 8 & 9 & 10 \\
\hline $\mathrm{Pb}$ & 40.06 & 38.91 & 39.38 & 39.41 & 39.94 & 38.82 & 40.57 & 40.32 & 40.57 & 40.89 & 41.81 \\
$\mathrm{Hg}$ & 0.07 & 0.00 & 0.00 & 0.12 & 0.16 & 0.16 & 0.00 & 0.00 & 0.00 & 0.15 & 0.08 \\
$\mathrm{Sb}$ & 38.80 & 39.78 & 40.23 & 40.17 & 39.99 & 38.56 & 39.28 & 37.99 & 37.49 & 36.88 & 37.58 \\
$\mathrm{~S}$ & 21.55 & 21.83 & 21.65 & 21.86 & 21.83 & 22.44 & 21.10 & 21.22 & 21.15 & 21.17 & 21.24 \\
\hline total & 100.47 & 100.52 & 101.26 & 101.56 & 101.92 & 99.98 & 100.95 & 99.53 & 99.20 & 99.10 & 100.71 \\
\hline $\mathrm{Pb}$ & 4.898 & 4.713 & 4.769 & 4.745 & 4.808 & 4.666 & 4.994 & 4.996 & 5.051 & 5.098 & 5.160 \\
$\mathrm{Hg}$ & 0.008 & 0.000 & 0.000 & 0.015 & 0.020 & 0.020 & 0.000 & 0.000 & 0.000 & 0.019 & 0.010 \\
\hline$\Sigma$ & 4.906 & 4.713 & 4.769 & 4.760 & 4.828 & 4.686 & 4.994 & 4.996 & 5.051 & 5.117 & 5.170 \\
\hline $\mathrm{Sb}$ & 8.071 & 8.200 & 8.290 & 8.231 & 8.192 & 7.887 & 8.228 & 8.011 & 7.941 & 7.825 & 7.892 \\
$\mathrm{~S}$ & 17.023 & 17.087 & 16.941 & 17.008 & 16.980 & 17.427 & 16.779 & 16.993 & 17.009 & 17.058 & 16.938 \\
\hline $\mathrm{N}$ & 1.93 & 1.80 & 1.80 & 1.81 & 1.86 & 1.88 & 1.93 & 1.99 & 2.04 & 2.12 & 2.12 \\
\hline $\mathrm{M}$ & & & & & & & &
\end{tabular}

Mean - průměr 10 bodových analýz, 1 - 10 jednotlivé bodové analýzy; koeficienty empirických vzorců počitány na bázi 30 apfu; $N$ - číslo homologu plagionitové skupiny (Makovicky 2019).

Tabulka 6 Chemické složení Pb-deficitního plagionitu z Mikulovického vrchu (hm. \%)

\begin{tabular}{|c|c|c|c|c|c|c|c|c|c|c|c|c|c|c|c|}
\hline & mean & 1 & 2 & 3 & 4 & 5 & 6 & 7 & 8 & 9 & 10 & 11 & 12 & 13 & . \\
\hline$b$ & .82 & 4.16 & 34.87 & 35.22 & 35.31 & 35.35 & 35.68 & 35.61 & 35.46 & 35.69 & 36.14 & 36.36 & 36.40 & 37.28 & 37.26 \\
\hline$n$ & 07 & 0.10 & 0.06 & 0.09 & 0.06 & 0.10 & 0.09 & 0.07 & .09 & 0.06 & 0.10 & 0.09 & 0.07 & .09 & 0.08 \\
\hline $\lg$ & 0.06 & 0.00 & 0.00 & 0.00 & 0.00 & 0.12 & 0.00 & 0.00 & 0.30 & 0.31 & 0.00 & 0.00 & 0.20 & .41 & 0.12 \\
\hline$b$ & 41.65 & 43.09 & 42.31 & 42.62 & 42.30 & 42.43 & 42.52 & 42.05 & 42.18 & 42.18 & 41.79 & 41.69 & 41.00 & 40.71 & 40.57 \\
\hline$S$ & 22.02 & 22.07 & 23.09 & 22.20 & 22.15 & 22.22 & 21.96 & 22.21 & 22.06 & 21.69 & 21.87 & 21.84 & 22.02 & 21.67 & 21.63 \\
\hline otal & 99.62 & 99.42 & 100.331 & 100.13 & 99.821 & 100.221 & 100.25 & 99.941 & 100.09 & 99.93 & 99.90 & 99.98 & 99.691 & 100.16 & 99.66 \\
\hline b & 4.313 & 4.095 & 4.083 & 4.204 & 4.228 & 4.218 & 4.280 & 4.259 & 4.251 & 4.316 & 4.359 & 4.388 & 4.389 & 4.525 & 4.538 \\
\hline n & 0.016 & 0.021 & 0.012 & 0.019 & 0.013 & 0.021 & 0.019 & 0.015 & 0.019 & 0.013 & 0.021 & 0.019 & 0.015 & 0.019 & 0.017 \\
\hline $\mathrm{tg}$ & 0.008 & 0.000 & 0.000 & 0.000 & 0.000 & 0.015 & 0.000 & 0.000 & 0.037 & 0.039 & 0.000 & 0.000 & 0.025 & 0.051 & 0.015 \\
\hline$\Sigma$ & 4.336 & 4.116 & 4.096 & 4.222 & 4.241 & 4.253 & 4.299 & 4.274 & 4.307 & 4.368 & 4.380 & 4.407 & 4.429 & 4.595 & 4.570 \\
\hline $\mathrm{Sb}$ & 8.534 & 8.790 & 8.432 & 8.657 & 8.620 & 8.615 & 8.680 & 8.559 & 8.605 & 8.681 & 8.577 & 8.562 & 8.413 & 8.409 & 8.408 \\
\hline 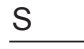 & 17.130 & 17.095 & 17.4721 & 17.1211 & 17.1391 & 17.1311 & 17.0211 & 17.1661 & 17.0881 & 16.951 & 17.043 & 17.0311 & 17.1581 & 16.996 & 17.022 \\
\hline$\Delta$ & 1.53 & 1.37 & 1.44 & 1.45 & 1.47 & 1.47 & 1.48 & 1.50 & 1.50 & 1.51 & 1.54 & 1.56 & 1.61 & 1.69 & 1.67 \\
\hline
\end{tabular}


plagionitem (obr. 8). Vzácnější jsou jeho až $1.5 \mathrm{~mm}$ velké krystaly. $V$ žilovině je poněkud častější než sfalerit a plagionit. Rentgenová prášková data fülöppitu (tab. 2) jsou v dobré shodě s publikovanými údaji pro tento minerální druh i teoretickým záznamem vypočteným z jeho krystalové struktury (Nuffield 1975). Zpřesněné parametry jeho základní cely jsou $v$ tabulce 3 porovnány s publikovanými údaji. Při studiu chemického složení fülöppitu z Mikulovického vrchu (tab. 4) byl pozorován vyšší rozsah variability obsahů $\mathrm{Pb} / \mathrm{Sb}$ (obr. 9) než v případě vzorků z Baia Mare (obr. 5) nebo Boněnova (obr. 10). Relativní deficit $\mathrm{Pb}$ se odráží i v hodnotách homologového čísla $N(0.68$ - 1.00), které je pro většinu bodových analýz nižší než teoretická hodnota 1 (Makovicky 2019). Za zmínku stojí i lokálně zjištěné minoritní obsahy $\mathrm{Hg}$ (do $0.63 \mathrm{hm}$. \%), Sn (do $0.15 \mathrm{hm}$. \%) a Se (do $0.23 \mathrm{hm}$. \%). Průměrné složení fülöppitu (93 bodových analýz) Ize na bázi 26 apfu vyjádřit empirickým vzorcem $\left(\mathrm{Pb}_{2.80} \mathrm{Sn}_{0.01} \mathrm{Hg}_{0.01}\right)_{\Sigma 2.82} \mathrm{Sb}_{8.18} \mathrm{~S}_{14.99}$.
Nejvíce $\mathrm{Pb}$-deficitní agregáty fülöppitu byly ověřeny pomocí Ramanovy spektroskopie (obr. 11); získaná spektra jsou prakticky identická s referenčním spektrem fülöppitu z Baia Mare v Rumunsku.

Plagionit je ve studovaných vzorcích výrazně vzácnější než fülöppit a vytváŕí v křemenné žilovině nepravidelné agregáty o délce do $200 \mu \mathrm{m}$ obvykle srůstající s fülöppitem (obr. 8). Při studiu chemického složení byly zjištěny dva typy plagionitu (obr. 9). Ojedinělé drobné izolované agregáty odpovídají velmi dobře stechiometrii (tab. 5) s homologovým číslem $N$ v rozmezí 1.80 - 2.12 (ideální hodnota $\mathrm{N}=2$; Makovicky 2019) a jejich průměrné složení (10 bodových analýz) Ize vyjádřit na bázi 30 apfu empirickým vzorcem $\left(\mathrm{Pb}_{4.90} \mathrm{Hg}_{0.01}\right)_{\Sigma 4.91} \mathrm{Sb}_{8.07} \mathrm{~S}_{17.02}$. Hojnější agregáty (obvykle srůstající s fülöppitem) jsou představovány zřetelně $\mathrm{Pb}$-deficitní fází (obr. 9) s hodnotami homologového čísla $N$ v rozmezí 1.37 - 1.74 (tab. 6). Chemicky obdobné agregáty zjištěné na lokalitě Boněnov
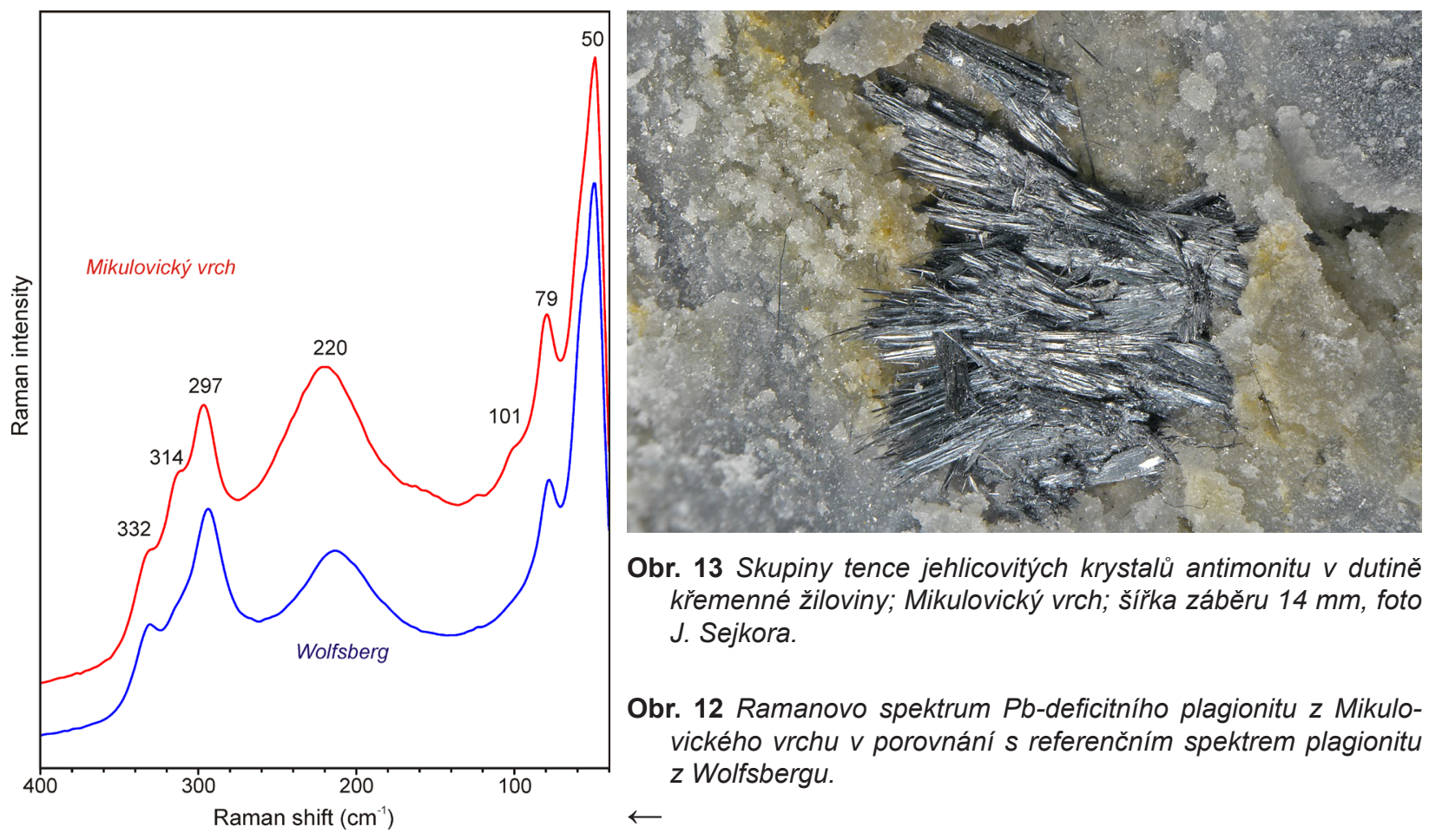

Obr. 13 Skupiny tence jehlicovitých krystalů antimonitu $v$ dutině křemenné žiloviny; Mikulovický vrch; šiřka záběru 14 mm, foto J. Sejkora.

Obr. 12 Ramanovo spektrum Pb-deficitního plagionitu z Mikulovického vrchu $v$ porovnání s referenčním spektrem plagionitu z Wolfsbergu.

Tabulka 7 Chemické složení antimonitu z Mikulovického vrchu (hm. \%)

\begin{tabular}{lrrrrrrrrrrrrrrr}
\hline & mean & 1 & 2 & 3 & 4 & 5 & 6 & 7 & 8 & 9 & 10 & 11 & 12 & 13 & 14 \\
\hline $\mathrm{Pb}$ & 0.58 & 0.08 & 0.14 & 0.17 & 0.23 & 0.26 & 0.30 & 0.33 & 0.34 & 0.38 & 0.39 & 0.41 & 0.83 & 1.50 & 2.76 \\
$\mathrm{Sn}$ & 0.11 & 0.00 & 0.14 & 0.12 & 0.16 & 0.12 & 0.00 & 0.16 & 0.00 & 0.17 & 0.14 & 0.15 & 0.13 & 0.13 & 0.12 \\
$\mathrm{Hg}$ & 0.16 & 0.32 & 0.07 & 0.09 & 0.45 & 0.00 & 0.00 & 0.19 & 0.19 & 0.00 & 0.21 & 0.51 & 0.23 & 0.00 & 0.00 \\
$\mathrm{Sb}$ & 70.65 & 70.94 & 71.12 & 71.56 & 71.15 & 70.70 & 70.92 & 70.18 & 70.79 & 70.60 & 70.80 & 70.50 & 71.07 & 70.58 & 68.25 \\
$\mathrm{~S}$ & 27.83 & 27.62 & 28.12 & 28.05 & 27.74 & 27.87 & 27.54 & 28.02 & 27.78 & 27.80 & 28.10 & 27.57 & 28.03 & 28.01 & 27.33 \\
\hline total & 99.33 & 98.96 & 99.59 & 99.99 & 99.73 & 98.95 & 98.76 & 98.88 & 99.10 & 98.95 & 99.64 & 99.14 & 100.29 & 100.22 & 98.46 \\
\hline $\mathrm{Pb}$ & 0.010 & 0.001 & 0.002 & 0.003 & 0.004 & 0.004 & 0.005 & 0.005 & 0.006 & 0.006 & 0.006 & 0.007 & 0.014 & 0.025 & 0.047 \\
$\mathrm{Sn}$ & 0.003 & 0.000 & 0.004 & 0.003 & 0.005 & 0.003 & 0.000 & 0.005 & 0.000 & 0.005 & 0.004 & 0.004 & 0.004 & 0.004 & 0.004 \\
$\mathrm{Hg}$ & 0.003 & 0.006 & 0.001 & 0.002 & 0.008 & 0.000 & 0.000 & 0.003 & 0.003 & 0.000 & 0.004 & 0.009 & 0.004 & 0.000 & 0.000 \\
$\mathrm{Sb}$ & 1.997 & 2.015 & 1.996 & 2.006 & 2.009 & 1.999 & 2.019 & 1.982 & 2.004 & 1.999 & 1.989 & 2.004 & 1.993 & 1.983 & 1.964 \\
\hline$\Sigma$ & 2.013 & 2.022 & 2.003 & 2.014 & 2.025 & 2.007 & 2.024 & 1.995 & 2.013 & 2.011 & 2.003 & 2.024 & 2.015 & 2.012 & 2.014 \\
\hline $\mathrm{S}$ & 2.987 & 2.978 & 2.997 & 2.986 & 2.975 & 2.993 & 2.976 & 3.005 & 2.987 & 2.989 & 2.997 & 2.976 & 2.985 & 2.988 & 2.986 \\
\hline
\end{tabular}

Mean - průměr 14 bodových analýz, 1 - 14 jednotlivé bodové analýzy; koeficienty empirických vzorců počítány na bázi 5 apfu. 
(obr. 10) byly interpretovány jako (sub)mikroskopické srůsty plagionitu a fülöppitu (Sejkora et al. 2017), čemuž odpovídal i jejich charakter v BSE obraze. Pb-deficitní fáze $z$ Mikulovického vrchu je však podle BSE obrazu homogenní. Vzhledem k tomu, že se její chemické složení blíží analýzám scainiitu $\left(\mathrm{Pb}_{14} \mathrm{Sb}_{10} \mathrm{~S}_{54} \mathrm{O}_{5}\right.$ - Orlandi et al. 1999; Moëlo et al. 2000) bylo pro jednoznačnou identifikaci využito Ramanovy spektroskopie. Získaná spektra minerálu z Mikulovického vrchu jsou prakticky identická s referenčním spektrem plagionitu z Wolfsbergu (obr. 12) a zřetelně odlišná od spekter fülöppitu i scainiitu (obr. 6). Je tedy zřejmé, že se jedná o mimořádně Pb-deficitní plagionit; jeho chemické složení (průměr 62 bodových analýz) je možno na bázi 30 apfu vyjádřit empirickým vzorcem $\left(\mathrm{Pb}_{4.31} \mathrm{Sn}_{0.02} \mathrm{Hg}_{0.01}\right)_{\Sigma 4.34} \mathrm{Sb}_{8.53} \mathrm{~S}_{17.13}$.

Hlavním rudním minerálem je antimonit, tvořící jehlicovité krystaly o délce do $5 \mathrm{~mm}$, zarostlé v křemeni, které mu dodávají světle až tmavě šedou barvu. Místy přechází v jemně stébelnaté až plstnaté agregáty. $V$ drobnějších dutinkách tvoří do prostoru vyvinuté drobné jehlice a snopkovité až plstnaté agregáty o velikosti do $10 \mathrm{~mm}$ (obr. 13), mnohdy $v$ asociaci se sfaleritem. Ojedinělé jsou jeho tlustě jehlicovité, až $7 \mathrm{~mm}$ dlouhé krystaly a jejich až $15 \mathrm{~mm}$ dlouhé hypoparalelní srůsty v puklinových dutinách asociující s fülöppitem, sfaleritem, ryzí sírou a sádrovcem. Nezřídka bývají jeho jehlice částečně až zcela nahrazené Sb-okry. Chemické složení antimonitu (tab. 7) odpovídá stechiometrii tohoto minerálního druhu; vedle $\mathrm{Sb}$ a $\mathrm{S}$ bylo zjištěno i minoritní zastoupení $\mathrm{Pb}$ (do 2.76 hm. \%), Hg (do $0.51 \mathrm{hm}$. \%) a Sn (do $0.17 \mathrm{hm}$. \%). Empirický vzorec antimonitu (průměr 14 bodových analýz) je možno na bázi 5 apfu vyjádřit jako $\left(\mathrm{Sb}_{2.00} \mathrm{~Pb}_{0.01}\right)_{\Sigma 2.01} \mathrm{~S}_{2.99}$.

$\mathrm{K}$ běžně zastoupeným sulfidům patří rovněž pyrit, který se častěji vyskytuje ve světlejším typu křemenné žiloviny; s rostoucím zastoupením antimonitu jeho obsah klesá. Tvoří většinou $1-5 \mathrm{~mm}$ velké zrnité agregáty zarůstající do křemene a vzácněji i do okoložilné pararuly. Ojediněle tvoří $\checkmark$ drobných dutinách malé pentagondodekaedrické krystaly. Problematická a analyticky nepotvrzená je prítomnost dalších sulfidů $\mathrm{Fe}$ - pyrhotinu a markazitu, které uvádí Rezek (1982). Ojediněle zjištěným sulfidem je arzenopyrit, který tvoří inkluze v pyritu o velikosti do $5 \mu \mathrm{m}$; vzhledem $\mathrm{k}$ minimálním rozměrům byl ověřen pomocí energiově disperzní analýzy.

Obr. 14 Krystaly ryzí síry narostlé na jehlicích antimonitu z Mikulovického vrchu; šiřka záběru $550 \mu \mathrm{m}$, foto $v$ BSE O. Pour.

Obr. 15 Pseudomorfózy valentinitu po jehlicovitých krystalech antimonitu $v$ dutině křemenné žiloviny; Mikulovický vrch; šiřka záběru $4 \mathrm{~mm}$, foto P. Fuchs.
Tabulka 8 Chemické složení sfaleritu z Mikulovického vrchu (hm. \%)

\begin{tabular}{lrrrrrrrrrr}
\hline & mean & 1 & 2 & 3 & 4 & 5 & 6 & 7 & 8 \\
\hline $\mathrm{Fe}$ & 0.49 & 0.19 & 0.45 & 0.46 & 0.46 & 0.47 & 0.58 & 0.64 & 0.64 \\
$\mathrm{Cd}$ & 0.31 & 1.22 & 0.30 & 0.11 & 0.15 & 0.07 & 0.14 & 0.23 & 0.22 \\
$\mathrm{Zn}$ & 64.23 & 64.21 & 61.39 & 64.61 & 65.04 & 65.36 & 64.23 & 64.26 & 64.77 \\
$\mathrm{Cu}$ & 0.15 & 0.00 & 0.83 & 0.00 & 0.00 & 0.00 & 0.08 & 0.19 & 0.07 \\
$\mathrm{Sb}$ & 0.77 & 0.56 & 2.44 & 0.65 & 0.22 & 0.23 & 0.55 & 0.99 & 0.53 \\
$\mathrm{~S}$ & 32.77 & 31.87 & 32.72 & 32.91 & 32.79 & 33.23 & 32.37 & 33.15 & 33.15 \\
$\mathrm{Cl}$ & 0.10 & 0.09 & 0.27 & 0.13 & 0.00 & 0.00 & 0.06 & 0.15 & 0.08 \\
\hline total & 98.81 & 98.14 & 98.40 & 98.87 & 98.66 & 99.36 & 98.01 & 99.61 & 99.46 \\
\hline $\mathrm{Fe}$ & 0.009 & 0.003 & 0.008 & 0.008 & 0.008 & 0.008 & 0.010 & 0.011 & 0.011 \\
$\mathrm{Cd}$ & 0.003 & 0.011 & 0.003 & 0.001 & 0.001 & 0.001 & 0.001 & 0.002 & 0.002 \\
$\mathrm{Zn}$ & 0.969 & 0.983 & 0.934 & 0.972 & 0.981 & 0.977 & 0.977 & 0.961 & 0.969 \\
$\mathrm{Cu}$ & 0.002 & 0.000 & 0.013 & 0.000 & 0.000 & 0.000 & 0.001 & 0.003 & 0.001 \\
$\mathrm{Sb}$ & 0.006 & 0.005 & 0.020 & 0.005 & 0.002 & 0.002 & 0.004 & 0.008 & 0.004 \\
\hline$\Sigma$ & 0.989 & 1.002 & 0.978 & 0.987 & 0.992 & 0.987 & 0.994 & 0.985 & 0.987 \\
\hline $\mathrm{S}$ & 1.008 & 0.995 & 1.015 & 1.010 & 1.008 & 1.013 & 1.004 & 1.011 & 1.011 \\
$\mathrm{Cl}$ & 0.003 & 0.003 & 0.008 & 0.004 & 0.000 & 0.000 & 0.002 & 0.004 & 0.002 \\
\hline$\Sigma$ & 1.011 & 0.998 & 1.022 & 1.013 & 1.008 & 1.013 & 1.006 & 1.015 & 1.013 \\
\hline
\end{tabular}

Mean - průměr osmi bodových analýz, 1 - 8 jednotlivé bodové analýzy; koeficienty empirických vzorců počítány na bázi 2 apfu.
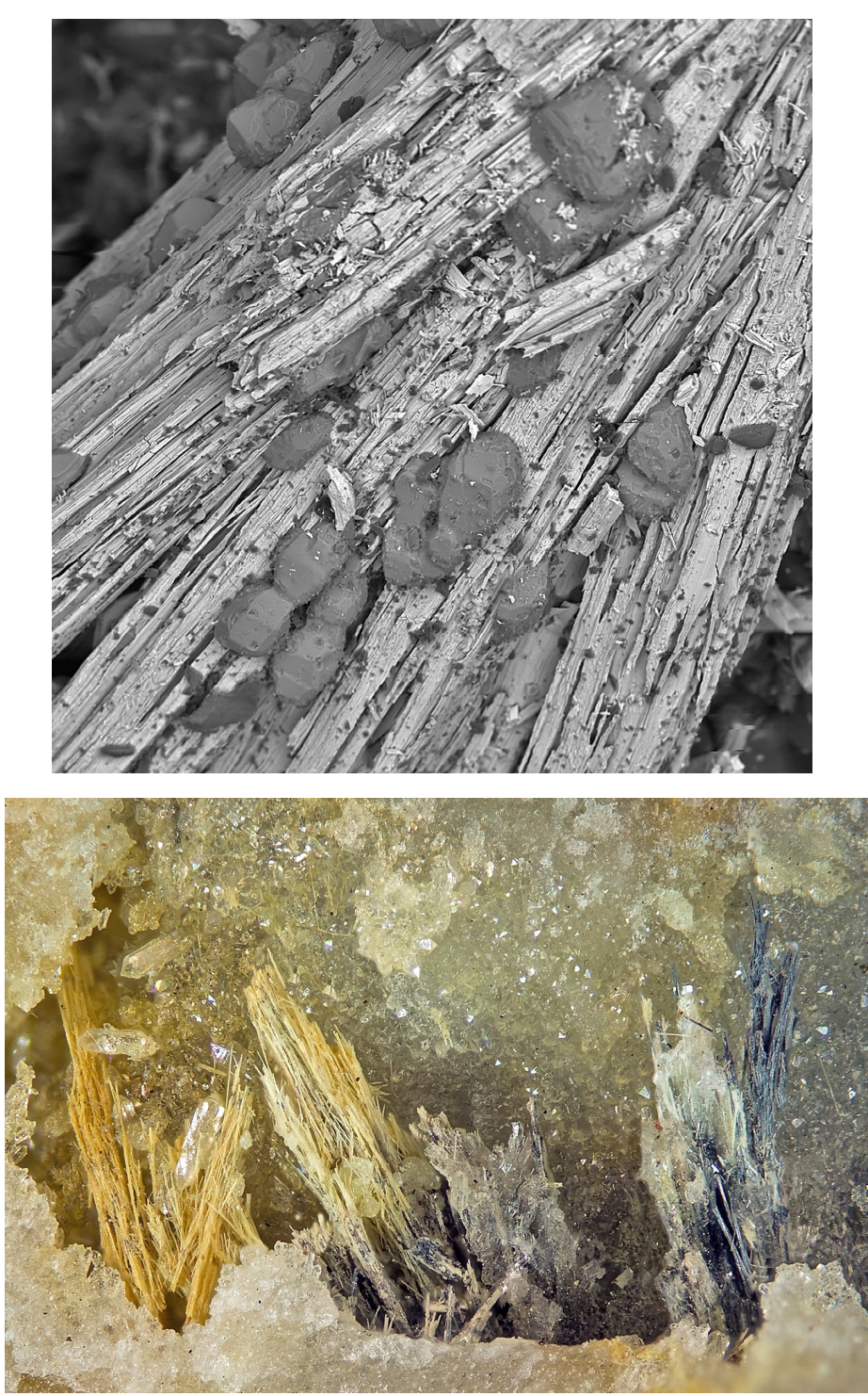


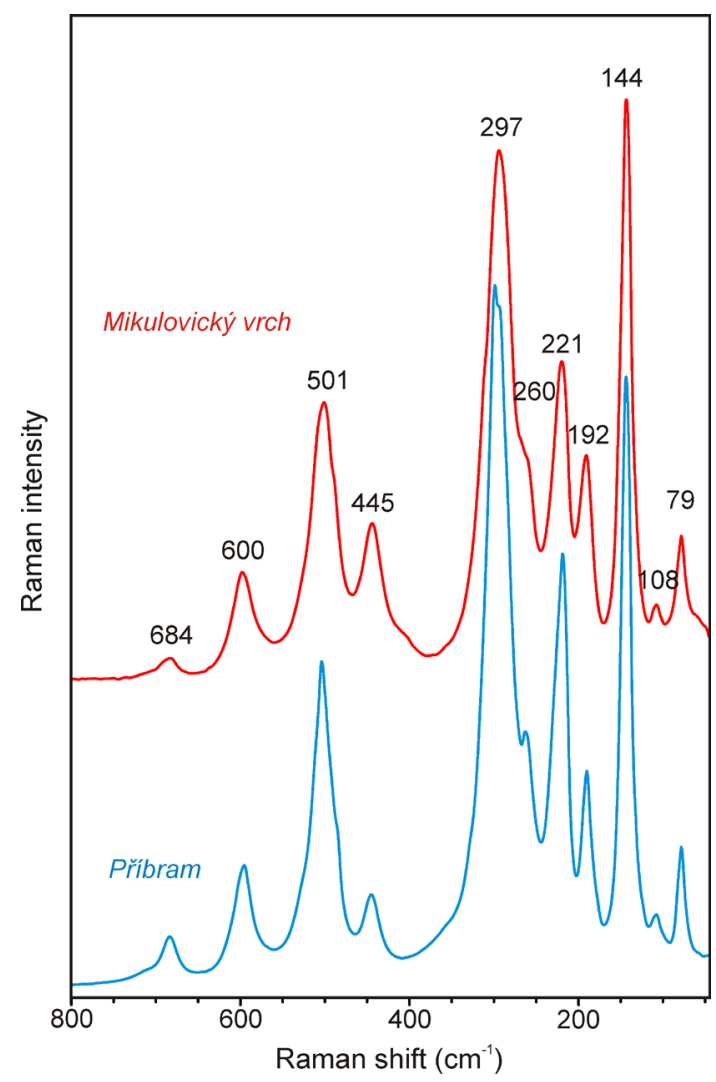

Obr. 16 Ramanovo spektrum valentinitu z Mikulovického vrchu v porovnání s referenčním spektrem valentinitu z Príibrami - Březových Hor.

Poměrně řídký je sfalerit, který tvoří bud' zrnité hnízdovité agregáty $v$ tmavě šedém křemeni anebo častěji doprovází antimonit a fülöppit $v$ drúzových dutinách $v$ podobě drobných izometrických krystalů o velikosti 0.1 $0.5 \mathrm{~mm}$, oranžové až medově hnědé barvy. Po chemické stránce (tab. 8) je sfalerit chudý Fe (do $0.64 \mathrm{hm}$. \%) se zvýšenými obsahy Cd (do $1.22 \mathrm{hm}$. \%) a nepravidelnými minoritními obsahy $\mathrm{Cu}$ (do $0.83 \mathrm{hm}$. \%), Sb (do $2.44 \mathrm{hm}$. $\%$ ) a $\mathrm{Cl}$ (do $0.27 \mathrm{hm}$. \%). Jeho průměrné chemické složení (osm bodových analýz) je možno na bázi 2 apfu vyjádřit empirickým vzorcem $\left(\mathrm{Zn}_{0.97} \mathrm{Fe}_{0.01} \mathrm{Sb}_{0.01}\right)_{\Sigma 0.99} \mathrm{~S}_{1.01}$.

\section{Charakteristika supergenní mineralizace}

Supergenní mineralizace je reprezentovaná především charakteristickými světle hnědými oxidační lemy kolem zrn fülöppitu a žlutými Sb-okry na puklinách a v dutinách $s$ antimonitem. $V$ několika málo dutinách se vyskytla ryzí síra, tvořící lesklé, světle žluté, izometricky hojnoploché krystaly o velikosti $0.1-0.5 \mathrm{~mm}$, které narůstají na jehlice antimonitu a křemen (obr. 14). Tento výskyt krystalované ryzí síry má obdobný charakter jako již dříve studované nálezy ze štoly sv. Antonína Paduánského v Kutné Hoře (Pauliš et al. 2012) či z kamenolomu ve Vlastějovicích (Kadlec 2009). V obou těchto př́ipadech však narůstá ryzí síra na jehlice berthieritu. Určení síry bylo ověřeno energiově disperzním spektrometrem.

Místy častější je sádrovec, tvořící $v$ dutinách samostatné čiré prizmatické krystaly nebo jejich ježkovité srůsty. Jejich délka obvykle nepřesahuje $3 \mathrm{~mm}$, největší nalezený krystal dosáhl rozměrů $10 \times 1 \mathrm{~mm}$. Vedle morfologického charakteru byl ověřen i pomocí rentgenových práškových dat.
Dominantní součástí žlutých a bílých Sb-okrů, které vytvářejí povlaky na puklinách křemené žiloviny a až 1 $\mathrm{mm}$ velké pseudomorfózy po jehlicovitých krystalech antimonitu (obr. 15), je valentinit. Vedle energiově disperzní analýzy byl ověřen i pomocí Ramanovy spektroskopie; získaná spektra jsou velmi blízká referenčnímu spektru valentinitu z Příbrami - Březových Hor (obr. 16). Vedlejší součástí některých povlaků žlutých Sb-okrů je i jarosit, potvrzený pomocí rentgenové práškové difrakce a energiově disperzní analýzy.

\section{Závěr}

Zjištěná sulfidická mineralizace $s$ antimonitem, fülöppitem a plagionitem z Mikulovického vrchu je po chemické i paragenetické stránce obdobná mineralizaci z Boněnova u Chodové Plané (Sejkora et al. 2017). Vedle topografické vzdálenosti je zřetelně odlišná jejich geologická pozice, žíly v Boněnově jsou vyvinuty v metabazitech, na Mikulovickém vrchu ve světlých pararulách. Pro nově studovaný výskyt na Mikulovickém vrchu je také charakteristická úplná absence karbonátů v žilovině.

\section{Poděkování}

Milou povinností autorů je poděkovat Zdeňku Dolníčkovi z Národního muzea v Praze za spolupráci při laboratorním výzkumu a Petru Fuchsovi za poskytnutí fotografií. Předložená práce vznikla za finanční podpory Ministerstva kultury Č $R$ v rámci institucionálního financování dlouhodobého koncepčního rozvoje výzkumné organizace Národní muzeum (DKRVO 2019-2023/1.I.b, 00023272).

\section{Literatura}

Bambas J (1990) Březohorský rudní revír. Publ symp Horn Príbram ve vědě a techn Príbram

Burnham CHW (1962) Lattice constant refinement. Carnegie Inst Washington Year Book 61: 132-135

EDENHARTER A, NoWACKI W (1975). Die Kristallstruktur von Fülöppit ( $\left.\mathrm{Sb}_{8} \mathrm{~S}_{15} \mid \mathrm{Pb}^{\text {VIIII }} \mathrm{Pb}_{2}{ }^{\mathrm{VII}}\right)$. Zeit Krist 142(8): 196-215

KADLEC T (2009) Antimonová mineralizace ve Vlastějovicích. Minerál 17(3): 220-228

Kratochvíl J (1963) Topografická mineralogie Čech VI. NČAV Praha

Lafuente B, Downs RT, Yang H, Stone N (2015) The power of databases: the RRUFF project. In: Armbruster T, Danisi RM, eds, Highlights in Mineralogical Crystallography, Berlin, Germany, W. De Gruyter, 1-30

Litochleb J, Šrein V, Skála R, Černý P (1994) Parageneze andoritu se sulfoantimonidy olova $\mathrm{z} \mathrm{Pb}-\mathrm{Zn}$-Ag ložiska Příbram - Březové Hory (šachta Lill). In: Sbor Mineralogie, geochemie a životní prostředí, Ostrava-Poruba (Praha), Čes geol Úst, 10-12

MAKOVICKY E (2019) Algorithms for calculations of homologue order $\mathrm{N}$ in the homologous series of sulfosalts. Eur J Mineral 31: 83-97

Moëlo Y, Meerschaut A, Orlandi P, Palvadeau P (2000) Lead-antimony sulfosalts from Tuscany (Italy) II-Crystal structure of scainiite, $\mathrm{Pb}_{14} \mathrm{Sb}_{30} \mathrm{~S}_{54} \mathrm{O}_{5}$, an expanded monoclinic derivative of $\mathrm{Ba}_{12} \mathrm{Bi}_{24} \mathrm{~S}_{48}$ hexagonal sub-type (zinkenite group). Eur J Mineral 12(4): 835-846

Nuffield EW (1975) The crystal structure of fülöppite, $\mathrm{Pb}_{3} \mathrm{Sb}_{8} \mathrm{~S}_{15}$. Acta Cryst B31: 151-157

ONDRUŠ P (1993) ZDS - A computer program for analysis of X-ray powder diffraction patterns. Materials Science Forum, 133-136, 297-300, EPDIC-2. Enchede 
Orlandi P, Moëlo Y, Meerschaut A, Palvadeau P (1999) Lead-antimony sulfosalts from Tuscany (Italy); I, Scainiite, $\mathrm{Pb}_{14} \mathrm{Sb}_{30} \mathrm{~S}_{54} \mathrm{O}_{5}$, the first $\mathrm{Pb}$-Sb oxy-sulfosalt, from Buca della Vena Mine. Eur J Mineral 11(6): 949-954

Pauliš P, Kadlec T, JebavÁ I (2012) Ryzí síra ze štoly Sv. Antonína Paduánského u Kutné Hory. Minerál 20, 6: 501-502

Pouchou JL, PICHOIR F (1985) "PAP" ( $\varphi \rho Z)$ procedure for improved quantitative microanalysis. In: Microbeam Analysis (J. T. Armstrong, ed.). San Francisco Press, San Francisco, 104-106

RezEK K (1982) Antimonit z Kadaně. Čas Mineral Geol 27(2): 205-206

SEJKoRA J, Litochleb J (2003) Die primäre Mineralisation der Príbramer Erzzone und ihre interessantesten Mineralien. Lapis 28(7-8): 32-59
Sejkora J, Pauliš P, Gramblička R, Malíková R (2017) Fülöppit a plagionit $z$ antimonového ložiska Boněnov u Chodové Plané (Česká republika). Bull Mineral Petrolog 25(2): 201-208

ŠKÁCHA P (2015) Novinky z mineralogie březohorského a přibramského uran-polymetalického revíru. Minerál 23(1): 24-35

ŽÁČEK V, FRÝdA J, ONDRUŠ P, OPLUŠTIL S (1994) Polymetalická mineralizace $v$ proterozoiku v podloží karbonské pánve na dole Slaný. Bull. mineral.-petrolog. Odd. Nár. Muz. (Praha) 2: 123-126

ŽÁČEK V, OPLUŠTIL S (1992) Eine ungewöhnliche Sulfid-Vererzung neben Dawsonit aus dem Bergbau von Slaný in Mittelböhmen, CSFR. Mineralien Welt 1: 27-29 